\title{
Faktor-Faktor yang Mempengaruhi terjadinya Blighted Ovum (BO) pada Ibu Hamil di Rumah Sakit dr. Zainoel Abidin Kota Banda Aceh Tahun 2015
}

\author{
Factors Affecting The Occurrence of Blighted Ovum (BO) in Pregnant Women \\ at The Hospital dr. Zainoel Abidin City of Banda Aceh 2015 \\ Raudhatun Nuzul ZA ${ }^{1 *}$, Eva Rosdiana ${ }^{2}$ \\ ${ }^{1,2}$ Program Studi D-IV Kebidanan, Fakultas Ilmu Kesehatan, Universitas Ubudiyah Indonesia, Banda Aceh, Indonesia \\ *Korespondensi Penulis: raudhatun@uui.ac.id
}

\begin{abstract}
Abstrak
Blighted ovum adalah suatu keadaan hasil konsepsi yang tidak mengandung janin. Diperkirakan di seluruh dunia. Blighted ovum merupakan $60 \%$ dari penyebab kasus keguguran, di Indonesia ditemukan 37\% dari setiap 100 kehamilan. Penelitian inibersifat analitik dengan pendekatan case control. Sampel adalah seluruh ibu hamil, sampel 36 orang ibu-ibu hamil yang mengalami blighted ovum dan 36 orang ibu-ibu hamil normal yaitu sebanyak 72 orang. Teknik pengambilan sampel menggunakan purposive sampling Pengumpulan data dilakukan dengan menggunakan cheklist. Dari 72 responden terdapat 12 orang ibu hamil dari kelompok usia yang beresiko terjadinya blighted ovum, sedangkan 60 orang lagi tidak beresiko terjadinya blighted ovum, nilai odds ratio 3.667, dan pada kelompok paritas terdapat 20 orang ibu hamil yang beresiko tinggi terjadinya blighted ovum dan 52 orang lagi tidak beresiko tinggi terjadinya bligted ovum, nilai Odds ratio 3.504 .
\end{abstract}

Kata Kunci: Blighted Ovum, Usia, Paritas

\begin{abstract}
Blighted ovum is a state of conception that does not contain a fetus. It is estimated that in the whole world Blighted ovum constitutes $60 \%$ of the causes of miscarriages, in Indonesia $37 \%$ of every 100 pregnancies are found. Method: This study is analytical with a case-control approach. The sample was all pregnant women, 36 samples of pregnant women who had blighted ovum and 36 normal pregnant women were 72 people. The sampling technique uses purposive sampling Data collection is done using a checklist. From 72 respondents there were 12 pregnant women from the age group who were at risk of a blighted ovum, while 60 people were not at risk of a blighted ovum, the odds ratio was 3,667. And in the parity group there were 20 pregnant women who were at high risk of blighted ovum and 52 people were not at high risk of the blighted ovum, the Odds ratio was 3.504.
\end{abstract}

Keywords: Blighted Ovum, Age, Parity 


\section{PENDAHULUAN}

Menurut data WHO (world health organization) persentase kemungkinan terjadinya abortus cukup tinggi sekitar 15-40\%. Di Indonesia, diperkirakan ada 500.000-750.000 kejadian abortus. Blighted ovum adalah suatu keadaan hasil konsepsi yang tidak mengandung janin. Diperkirakan di seluruh dunia Blighted ovum merupakan 60\% dari penyebab kasus keguguran, di ASEAN (association of southeast asian nations) mencapai 51\%, di Indonesia ditemukan 37\% dari setiap 100 kehamilan, di Provinsi Lampung mencapai 30\% dari 100 kehamilan dan di Kota Metro sebanyak 43,39\%. Angka kejadian di Permata Hati Lampung menunjukkan peningkatan angka Blighted ovum selama 3 tahun terakhir tahun 2009 sebanyak $6,02 \%$, tahun 2010 meningkat 6,05\%, dan pada tahun 2011 meningkat 6,06\%. Ibu-ibu yang mengalami abortus karena blighted ovum memiliki karakteristik antara lain usia, paritas dan jarak kehamilan, selain itu usia, paritas dan jarak kehamilan juga merupakan faktor penyebab terjadinya blighted ovum.

Angka kematian ibu di Indonesia tertinggi di Asia Tenggara yaitu sebesar 195 per 100.000 kelahiran hidup. Diharapkan pada tahun 2019 kematian ibu bisa lebih berkurang menjadi 60-80 per 100.000 kelahiran hidup. Penyebab kematian ibu terbanyak disebabkan oleh perdarahan, eklamsia, sepsis, dan komplikasi dari keguguran. Menurut kejadian kematian ibu di Indonesia disebabkan oleh perdarahan sebesar 40-60\%, infeksi 20-30\%, dan keracunan 20-30\% sisanya sekitar 5\% disebabkan penyakit lain. Dan juga kematian ibu disebabkan oleh keterlambatan rujukan dan transportasi yang sulit (Niken, 2009).

Blighted ovum adalah keadaan dimana seorang wanita merasa hamil tetapi tidak ada bayi di dalam kandungan. Seorang wanita yang mengalaminya juga merasakan gejala-gejala kehamilan seperti terlambat menstruasi, mual dan muntah pada awal kehamilan (morning sickness), payudara mengeras, serta terjadi pembesaran perut, bahkan saat dilakukan tes kehamilan baik test pack maupun laboratorium hasilnya pun positif. Pada saat konsepsi, sel telur (ovum) yang matang bertemu sperma. Namun akibat berbagai faktor maka sel telur yang telah dibuahi sperma tidak dapat berkembang sempurna, dan hanya terbentuk plasenta yang berisi cairan. Meskipun demikian plasenta tersebut tetap tertanam di dalam rahim. Plasenta menghasilkan hormon HCG (humanchorionic gonadotropin) dimana hormon ini akan memberikan sinyal pada indung telur (ovarium) dan otak sebagai pemberitahuan bahwa sudah terdapat hasil konsepsi di dalam rahim. Hormon HCG yang menyebabkan munculnya gejalagejala kehamilan seperti mual, muntah, ngidam dan menyebabkan tes kehamilan menjadi 
positif. Karena tes kehamilan baik test pack maupun laboratorium pada umumnya mengukur kadar hormon yang sering disebut juga sebagai hormon kehamilan (Fika, 2011).

Blighted ovum atau kehamilan kosong ini, kadang di sebagian masyarakat ada yang menghubungkannya dengan hal-hal mistik. Ada yang mengatakan kehamilannya hilang di bawa oleh makhlus atau bayinya dipindahkan ke orang lain, dll. Karena memang kesannya bayinya menghilang, padahal ibu hamil yang mengalami blighted ovum mengalami tandatanda dan perubahan-perubahan tubuh layaknya kehamilan normal, namun ketika di cek USG janinnya tidak ada/tidak berkembang. Oleh sebab itu pemeriksaan untuk mendeteksi adanya blighted ovum sangat diperlukan (Wisudanti, 2013).

Dari data sekunder Rumah sakit Umum Daerah Banjarbaru satu tahun terakhir pasien yang melakukan kuretase dengan berbagai indikasi seperti keguguran (abortus) baik itu inkomplit ataupun abortus komplit terdapat 493 dan hanya terdapat 2 orang yang diindikasikan kuretase dengan blighted ovum atau janin yang tidak berkembang, dan pada tahun 2012 dari awal januari hingga bulan juli didapatkan bahwa kehamilan dengan janin yang tidak berkembang yaitu hanya 1 orang dan dilakukan kuretase. (RSUD Banjarbaru tahun 2011 dan 2012 bulan Januari-Juli).

Berdasarkan studi awal pendahuluan yang penulis lakukan di Rumah Sakit Zainoel Abidin dari buku register ruang Rekam Medik, dari Tahun 2013 jumlah keseluruhan ibu hamil dari bulan Januari sampai bulan Desember berkisar 2750 Orang dari 2750 tersebut ternyata 36 orang penderita blighted ovum dan 63 orang ibu-ibu hamil normal.Pada bulan Januari terdapat 248 orang ibu hamil diantaranya terdapat 2 penderita blighted ovum dan 1 orang ibu hamil normal, bulan februari 121 orang ibu hamil diantaranya terdapat 1 orang penderita blighted ovum dan 6 orang ibu hamil normal, bulan maret 201 orang ibu hamil diantarnya terdapat 2 penderita blighted ovum dan 7 orang ibu hamil normal, bulan april 190 orang ibu hamil diantaranya terdapat 2 orang penderita blighted ovum dan 5 orang ibu hamil normal, bulan mei 221 orang ibu hamil diantaranya terdapat 3 orang penderita blighted ovum dan 3 orang ibu hamil normal, bulan juni 198 0rang ibu hamil diantaranya terdapat 3 orang penderita blighted ovum dan 11 orang ibu hamil normal, bulan juli 326 orang ibu hamil diantaranya terdapat 2 orang penderita blighted ovum dan 8 orang ibu hamil normal, bulan agustus 208 orang ibu hamil diantaranya terdapat 2 orang penderita blighted ovum dan 6 orang ibu hamil normal, bulan september 273 orang ibu hamil diantaranya terdapat 4 orang penderita blighted ovum dan 3 orang ibu hamil normal, bulan oktober 250 orang ibu hamil 
diantaranya terdapat 5 orang penderita blighted ovum dan 4 orang ibu hamil normal, bulan november 231 orang ibu hamil diantaranya terdapat 5 orang penderita blighted ovum dan 5 orang ibu hamil normal, pada bulan desember 183 orang ibu hamil diantaranya terdapat 6 orang penderita blighyed ovum, dan 4 orang ibu hamil normal Terlepas dari jumlah kasus tersebut, salah satu akibat yang ditimbulkan dari blighted ovum adalah perdarahan yang menyebabkan kematian dan ada kemungkinan berulang lagi.

Berdasarkan masalah-masalah yang dikemukakan di atas maka penulis tertarik untuk mengambil judul "faktor-faktor yang mempengaruhi terjadinya blighted ovum (bo) pada ibu hamil di Rumah Sakit Umum Daerah dr. Zainoel Abidin Kota Banda Aceh tahun 2014”.

\section{METODE PENELITIAN}

Penelitian ini bersifat analitik dengan menggunakan pendekatan rangcangan case control dimana penelitian yang membandingkan antara kelompok kasus dengan kelompok kontrol untuk mengetahui proporsi kejadian berdasarkan riwayat ada tidaknya paparan. Data yang digunakan pada saat penelitian menggunakan data sekunder.

\section{HASIL DAN PEMBAHASAN}

Tabel 1. Pengaruh antara Blighted Ovum Dengan Usia ibu di RSUD dr. Zainoel Abidin Banda Aceh

\begin{tabular}{|c|c|c|c|c|c|c|c|c|c|}
\hline \multirow[t]{3}{*}{ No } & \multirow[t]{3}{*}{ Usia } & \multicolumn{5}{|c|}{ Blighted Ovum } & \multirow{3}{*}{\multicolumn{2}{|c|}{$\begin{array}{c}\mathrm{P} \\
\text { value }\end{array}$}} & \multirow{3}{*}{ OR } \\
\hline & & \multicolumn{2}{|c|}{ Kasus } & \multicolumn{2}{|c|}{ Kontrol } & \multirow[t]{2}{*}{ Total } & & & \\
\hline & & $\mathbf{f}$ & $\%$ & $\mathbf{f}$ & $\%$ & & & & \\
\hline 1 & Beresiko & 9 & 25 & 3 & 8 & 12 & & & \\
\hline 2 & Tidak Beresiko & 27 & 75 & 33 & 92 & 60 & 0,05 & 0,114 & 3,667 \\
\hline & Jumlah & 36 & 100 & 36 & 100 & 72 & & & \\
\hline
\end{tabular}

Berdasarkan Tabel 4.1 dari 36 responden kelompok kasus usia terdapat 75\% Tidak Beresiko terjadinya blighted ovum pada ibu hamil, dan $25 \%$ nya lagi Beresiko terjadinya Blighted Ovum pada ibu hamil. Dan pada kelompok kontrol dari 36 responden usia terdapat 92\% tidak beresiko terjadinya blighted ovum pada ibu hamil normal. Dan $8 \%$ nya lagi beresiko terjadinya blighted ovum pada ibu hamil. 
Hasil uji Odds Ratio dengan bantuan SPSS dengan derajat kepercayaan 95\% didapat nilai Odds Ratio $=3,667$ dimana nilai tersebut $\alpha=0,05$ sehingga dapat dilihat bahwa Jika nilai OR $\geq 1$ berarti faktor usia 3,667 kali beresiko terjadinya blighted ovum pada ibu hamil.

Tabel 2. Pengaruh antara Blighted Ovum dengan Paritas Ibu di RSUD dr. Zainoel Abidin Banda Aceh

\begin{tabular}{|c|c|c|c|c|c|c|c|c|c|}
\hline \multirow[t]{3}{*}{ No } & \multirow[t]{3}{*}{ Paritas } & \multicolumn{4}{|c|}{ Blighted Ovum } & \multirow{3}{*}{ Total } & \multirow{3}{*}{\multicolumn{2}{|c|}{ P value }} & \multirow{3}{*}{ OR } \\
\hline & & \multicolumn{2}{|c|}{ Kasus } & \multicolumn{2}{|c|}{ Kontrol } & & & & \\
\hline & & $\mathbf{f}$ & $\%$ & $\mathbf{f}$ & $\%$ & & & & \\
\hline 1 & Resti & 13 & 36,1 & 5 & 13,9 & 18 & \multirow{3}{*}{0,05} & \multirow{3}{*}{0,057} & \multirow{3}{*}{3,504} \\
\hline 2 & Tidak resti & 23 & 63,9 & 31 & 86,1 & 54 & & & \\
\hline & Jumlah & 36 & 100 & 36 & 100 & 72 & & & \\
\hline
\end{tabular}

Berdasarkan Tabel 2, dari 36 responden kelompok kasus paritas ibu yang tidak beresiko tinggi terjadinya blighted ovum pada ibu hamil sebanyak 23 (63,9 \%) orang , Sedangkan dari 36 responden kelompok kontrol paritas terdapat $31(86,1 \%)$ orang yang tidak beresiko tinggi dalam kehamilan normal. Hasil uji Odds Ratio dengan bantuan SPSS dengan derajat kepercayaan $95 \%$ didapat nilai Odds Ratio $=3,504$ dimana nilai tersebut $\alpha=0,05$ sehingga dapat dilihat bahwa Jika nilai $\mathrm{OR} \geq 1$ berarti faktor usia 3,504 kali beresiko terjadinya blighted ovum pada ibu hamil.

\section{Pembahasan}

1. Pengaruh usia dengan Blighted Ovum

Hasil penelitian menunjukkan bahwa dari 72 responden dan dari 36 responden kelompok kasus yang mengalami Blighted ovum pada ibu hamil terdapat 27 (75\%) responden yang tidak beresiko pada usia 20-35 tahun dan 9 (25\%) nya lagi beresiko terjadinya Blighted ovum pada usia $<20$ dan $\geq 35$ tahun, hasil analisis data menunjukkan bahwa ada faktor resiko yang menimbulkan faktor efek di rumah sakit umum daerah dr. Zainal abidin. Dan dari 36 responden kelompok kontrol yang tidak mengalami blighted ovum pada ibu hamil normal terdapat 33 (92\%) responden yang tidak beresiko pada usia 20-35 tahun dan 3 (8\%) nya lagi beresiko terjadinya Blighted ovum pada usia <20 dan $\geq 35$ tahun, hasil analisis data menunjukkan bahwa faktor usia 3 kali lebih beresiko menimbulkan blighted ovum pada ibu hamil di rumah sakit umum daerah dr. Zainal abidin. 
Hasil uji Odds Ratio dengan bantuan SPSS dengan derajat kepercayaan 95\% didapat nilai Odds Ratio $=3,667$ dimana nilai tersebut $\alpha=0,05$ sehingga dapat dilihat bahwa Jika nilai OR $\geq 1$ berarti faktor usia 3,667 kali beresiko terjadinya blighted ovum pada ibu hamil. Blighted ovum atau kehamilan kosong terjadi ketika sel telur yang dibuahi tertanam dalam rahim, namun tidak berkembang menjadi embrio. Pada saat terjadi pembuahan, selsel tetap membentuk kantung ketuban, plasenta, namun telur yang telah dibuahi (konsepsi) tidak berkembang menjadi sebuah embrio, hal ini juga disebut sebagai kehamilan anembryonic dan merupakan penyebab utama kegagalan awal kehamilan atau keguguran. Pada kondisi blighted ovum kantung kehamilan akan terus berkembang, layaknya kehamilan biasa, namun sel telur yang telah dibuahi gagal untuk berkembang secara sempurna (Yoshie, 2013).

Hasil penelitian ini tidak sejalan dengan hasil penelitian ananda putri (2011), yang mengatakan bahwa usia berpengaruh terhadap terjadinya blighted ovum (bo) pada ibu hamil di Rumah Sakit Umum Daerah dr. Zainoel Abidin Kota Banda Aceh tahun 2014. Dimana diketahui bahwa hipotesa nol ditolak dan hipotesa alternatif diterima dengan diperoleh nilai $P$-Value adalah 0,015 .

Asumsi peneliti bahwa faktor usia 3,667 kali lipat lebih beresiko terjadinya blighted ovum pada ibu hamil karena usia mmemiliki resiko tinggi terhadap kehamilan dan persalinan ibu. Usia yang kemungkinan tidak resiko tinggi pada saat kehamilan dan persalinan yaitu umur 20-35 tahun, karena pada usia tersebut rahim sudah siap menerima kehamilan, mental sudah matang dan sudah mampu merawat bayi dan dirinya. Sedangkan umur $<20$ tahun dan $>35$ tahun merupakan umur yang resiko tinggi terhadap kehamilan dan persalinan.

Dengan demikian diketahui bahwa umur ibu pada saat melahirkan turut berpengaruh terhadap morbiditas dan mortalitas ibu maupun anak yang dilahirkan.25 Ibu yang berumur kurang dari 20 tahun rahim dan bagian tubuh lainnya belum siap untuk menerima kehamilan dan cenderung kurang perhatian terhadap kehamilannya. Ibu yang berumur 2035 tahun rahim dan bagian tubuh lainnya sudah siap untuk menerima dan diharapkan untuk memerhatikan kehamilannya. Ibu yang berumur lebih dari 35 tahun rahim dan bagian tubuh lainnya fungsinya sudah menurun dan kesehatan tubuh ibu tidak sebaik saat berumur 20-35 tahun. 


\section{Pengaruh paritas dengan Blighted Ovum}

Hasil penelitian menunjukkan bahwa dari 72 responden dan terdapat 36 responden kelompok kasus paritas pada ibu-ibu mengalami blighted ovum yang beresiko tinggi sebanyak 36,1\%, sedangkan yang tidak resti $63,9 \%$. Hasil analisis data menunjukkan bahwa tidak ada hubungan antara blighted ovum dengan paritas ibu di rumah sakit umum daerah dr. Zainal abidin. Hasil uji Odds Ratio dengan bantuan SPSS dengan derajat kepercayaan 95\% didapat nilai Odds Ratio $=3,504$ dimana nilai tersebut $\alpha=0,05$ sehingga dapat dilihat bahwa Jika nilai OR $\geq 1$ berarti faktor usia 3,504 kali beresiko terjadinya blighted ovum pada ibu hamil.Hasil analisis data menunjukkan bahwa faktor paritas 3 kali lipat lebih beresiko menimbulkan blighted ovum pada ibu hamil di rumah sakit umum daerah dr. Zainal abidin.

Menurut Manuaba (2008), paritas adalah wanita yang pernah melahirkan bayi aterm. Menurut Bobak (2004) mengatakan bahwa paritas adalah jumlah kehamilan yang menghasilkan janin hidup, bukan jumlah jani yang dilahirkan. Janin yang lahir hidup otomatis setelah viabilitas dicapai tidak mempengaruhi paritas. Semakin banyak jumlah kelahiran yang dialami seorang ibu semakin tinggi resikonya untuk mengalami komplikasi kehamilan, persalinan dan nifas (Mulyati, 2003). Sejalan dengan pendapat Cunningham (2006) bahwa resiko abortus spontan bisa terjadi semakin meningkat dengan bertambahnya paritas. Sedangkan blighted ovum adalah salah satu penyebab terjadinya abortus spontan. Persalinan kedua dan ketiga merupakan peralinan yang aman, sedangkan resiko terjadinya komplikasi meningkat pada kehamilan, persalinan dan nifas setelah ketiga dan seterunya.Demikian juga dengan paritas 0 dan lebih dari 4 merupakn kehamilan resiko tinggi (Mulyati, 2003).

Hasil penelitian ini tidak sejalan dengan hasil penelitian ananda putri (2011), yang mengatakan bahwa paritas berpengaruh terhadap terjadinya blighted ovum (bo) pada ibu hamil di Rumah Sakit Umum Daerah dr. Zainoel Abidin Kota Banda Aceh tahun 2013. Dimana diketahui bahwa hipotesa nol ditolak dan hipotesa alternatif diterima dengan diperoleh nilai $P$-Value adalah 0,028.Penelitian yang dilakukan oleh ananda putri bahwa karakteristik ibu hamil yang mengalami BO terbanyak dengan usia 20-35 tahun paritas multipara dan jarak kehamilan $>2$ tahun. Oleh karena itu pada ibu hamil untuk melakukan ANC minimal 4 kali selama kehamilan dan bila terdapat kelainan maka dilakukan kolaborasi dengan dokter spesialis kandungan. 
Asumsi peneliti bahwa faktor usia 3,504 kali lipat lebih beresiko terjadinya blighted ovum pada ibu hamil. karena Semakin banyak jumlah kelahiran yang dialami seorang ibu semakin tinggi resikonya untuk mengalami komplikasi kehamilan, persalinan dan nifas. Paritas 2-3 merupakan paritas paling aman ditinjau dari sudut kematian maternaldan tidak terancam terhadap ancaman mortalitas dan morbiditas baik pada ibu maupun pada janin. Ibu hamil yang telah melahirkan lebih dari 5 kali atau mempunyai resiko tinggi dalam kehamilan yang akan dapat mengakibatkan kematian janin. Persalinan kedua dan ketiga merupakan peralinan yang aman, sedangkan resiko terjadinya komplikasi meningkat pada kehamilan, persalinan dan nifas setelah ketiga dan seterunya. Demikian juga dengan paritas 0 dan lebih dari 4 merupakn kehamilan resiko tinggi Resiko pada paritas 1 dapat ditangani dengan asuhan obstetrik lebih baik, sedangkan resiko pada paritas tinggi dapat dikurangi atau dicegah dengan KB.

\section{KESIMPULAN}

Berdasarkan hasil penelitian yang telah dilakukan Di Rumah Sakit Umum Daerah dr. Zainoel Abidin Kota Banda Aceh, maka dapat disimpulkan sebagai berikut Faktor usia 3,667 kali lebih beresiko terjadinya blighted ovum (bo) pada ibu hamil di Rumah Sakit Umum Daerah dr. Zainoel Abidin Kota Banda Aceh tahun 2014. Faktor paritas 3,667 kali beresiko terjadinya blighted ovum (bo) pada ibu hamil di Rumah Sakit Umum Daerah dr. Zainoel Abidin Kota Banda Aceh tahun 2014.

\section{SARAN}

Bagi ibu diharapkan kepada ibu agar lebih menjaga kehamilan, sehingga tidak terjadi blighted ovum.

\section{DAFTAR PUSTAKA}

Anna P.Bani, dkk. (2009). Kamu Saku Mosby,edisi 4. Jakarta: EGC

Alan Serman, dkk. (2006). Gycosylation Patter Of Plasental Proteins In Blighted Ovum. Departemen of gynaecologi and obsteriies, general hospital svetiduh faculty of medicine, institute of biology, university of zagreb gynaecol perinatol.

Budiarto. (2002). Biostatistik Untuk Kedokteran Dan Kesehatan Masyarakat. EGC. Jakarta

Cunningham, F. Gary. dkk. 2006. Obstetri Williams. Edisi 21. Jakarta: Buku Kedokteran EGC. 
Efendi, nasrul. (1998). Dasar Keperawatan Masyarakat. Edisi 2. Jakarta : FKUI.

Hestiantoro, Andon. (2007). Blighted Ovum. Jakarta : RSCM.

Hellen, v. (2011). Buku Saku Bidan, jakarta EGC.

Helen. (2002). Buku Ajar Asuhan Kebidanan. Buku Kedokteran. EGC, Jakarta

JHPIEGO. (2007). Asuhan Persalinan Normal, jakarta : JNPK-KR

Revina. (2013). Mengenal Kehamilan kosong atau Blighted Ovum (BO), [internet], tersedia dalam http://bidan.com/mengenal-kehamilan-kosong-atau blightedovum-bo, [diakses tanggal 17 februari 2014]

Saifuddin, A.B. (2002). Pelayanan Kesehatan Maternal Dan Neonatus, jakarta : YHB-SP.

Sari, Yunita Niken. (2009). Karakteristik ibu hamil, [internet], tersedia dalam http://www.bascommetro.com/2013/03/karakteristik-ibu-hamil- yangmengalami.html, [diakses tanggal 17 februari 2014]

WHO. (2003). Departemen Of Child And Adolescent Health And Development, Jakarta. 